\title{
BIBECHANA
}

ISSN 2091-0762 (Print), 2382-5340 (Online)

Journal homepage: http://nepjol.info/index.php/BIBECHANA

Publisher: Department of Physics, Mahendra Morang A.M. Campus, TU, Biratnagar, Nepal

\section{Radon study around earthquake affected areas of Nepal}

\author{
Bipin Rijal', Nigam S. Silwal ${ }^{1}$, Govinda Chaudhary ${ }^{2}$, Pitamber Shrestha ${ }^{2}$, Buddha R. \\ Shah ${ }^{1, *}$ \\ ${ }^{1}$ Physical Science Laboratory, Faculty of Science, Nepal Academy of Science and Technology \\ (NAST), Khumaltar, Lalitpur, GPO 3323 Kathmandu, Nepal \\ ${ }^{2}$ Department of Physics, Amrit Science Campus, Thamel, Kathmandu, Nepal \\ *E-mail: buddharshah25@gmail.com
}

Article Information:

Received: July 3, 2020

Accepted: March 13, 2021

Keywords:

Indoor radon

Annual effective dose

Earthquake

LR 115

SSNTD

\begin{abstract}
Indoor radon concentrations were measured in dwellings of the earthquake affected areas of Kathmandu valley, Gorkha and Sindhupalchowk districts of Nepal using passive radon dosimeter LR115, a Solid-State Nuclear Track Detector, SSNTD. The radon concentrations in dwellings of Kathmndu valley ranged from $11 \pm 6 \mathrm{~Bq} / \mathrm{m}^{3}$ to $135 \pm 26 \mathrm{~Bq} / \mathrm{m}^{3}$ with mean of $67.63 \mathrm{~Bq} / \mathrm{m}^{3}$. For Gorkha it ranged from $18 \pm 7 \mathrm{~Bq} / \mathrm{m}^{3}$ to $363 \pm 65 \mathrm{~Bq} / \mathrm{m}^{3}$ with an average of 104.64 $\mathrm{Bq} / \mathrm{m}^{3}$ while minimum, maximum and average radon concentrations for Sindhupalchowk were $14 \pm 6 \mathrm{~Bq} / \mathrm{m}^{3}, 397 \pm 71 \mathrm{~Bq} / \mathrm{m}^{3}$ and $78.46 \mathrm{~Bq} / \mathrm{m}^{3}$ respectively. The average annual effective dose to the inhabitants of Kathmandu valley, Gorkha and Sindhupalchowk districts were calculated as $1.46 \mathrm{mSv} / \mathrm{y}, 2.26 \mathrm{mSv} / \mathrm{y}$ and $1.69 \mathrm{mSv} / \mathrm{y}$ respectively. These annual doses were well below the action level of $10 \mathrm{mSv} / \mathrm{y}$ recommended by International Commission on Radiological Protection (ICRP) which implies no significant radiological health hazards. Also, Excess Lifetime Cancer Risk and Lungs Cancer Cases per year per million people were determined.
\end{abstract}

DOI: https://doi.org/10.3126/bibechana.v18i2.29840

This work is licensed under the Creative Commons CC BY-NC License. https://creativecommons.org/licenses/by-nc/4.0/

\section{Introduction}

Radon $\mathrm{Rn}-222$ is a radioactive gas derived from Uranium-238 decay series. Uranium is a ubiquitous radioactive element present in varying amount in rock, soil and air. Radon has a half-life of 3.8 days that is sufficient for it to migrate through pore space in the soil and rock into dwellings. Despite being a member of noble gases, it spontaneously decays into very high alpha emitters such as Polonium-218 and Polonium-214.

Radon and its progenies represent more than 50\% of the total natural radiation of human exposure to ionizing radiation [1]. Radon is considered as carcinogenic to human [2]. It stands second to cause lungs cancer after tobacco smoking in general population [3]. Apart from lungs cancer, 
radon exposure is also responsible for various noncancerous diseases like stroke, heart disease and diseases related to respiratory and digestive system $[1,4]$. Studies on risk assessment of radon, both in mines and dwellings, have shown several health effects $[5,6]$ and the regulatory requirement has been advised to control public exposure due to radon indoors [7].

An earthquake of magnitude 7.6 struck on 25th April 2015 in Nepal and was followed by several aftershocks [8]. Gorkha district, Kathmandu valley and Sindhupalchowk district were the most affected by this earthquake. The cracks and fissures developed on soil due to earthquake or landslides are supposed to enhance radon exhalation from soil [9-12]. As Nepal is prone to earthquake, the assessment of radon concentration has become necessary as a baseline study for future investigation. Therefore, assessment of the indoor radon concentrations has been carried out starting from those most affected areas. In addition, the annual effective dose along with any cancerous risk associated with this radon exposure has been estimated around the earthquake-affected areas of Nepal.

\section{Materials and Methods}

\subsection{Study area}

Kathmandu valley, Gorkha and Sindhupalchowk were selected for this study. Kathmandu valley is comprised of three districts Kathmandu, Lalitpur and Bhaktapur and is the capital city of Nepal located at $27^{\circ} 42^{\prime} \mathrm{N}$ and $85^{\circ} 18^{\prime} \mathrm{E}$ with an average altitude of $1292 \mathrm{~m}$. Gorkha district, the other location is about $80 \mathrm{~km}$ northwest of Kathmandu valley with an average altitude of $1900 \mathrm{~m}$ from sea level having coordinates $28^{\circ} 12^{\prime} \mathrm{N}$ and $84^{\circ} 44^{\prime} \mathrm{E}$. The epicenter of 2015 earthquake was in Gorkha. Sindhupalchowk, the third location, is $60 \mathrm{~km}$ east from Kathmandu with an average elevation of 1450 $\mathrm{m}$ located at $27^{\circ} 46^{\prime} \mathrm{N}$ and $85^{\circ} 43^{\prime} \mathrm{E}$.

\subsection{Methodology}

Solid State Nuclear Track Detector, a passive radon detector (LR-115 type II, Dosirad, France) was employed for radon concentration measurement. Each detector consists of $12 \mu \mathrm{m}$ thick Cellulose Nitrate film coated on a $100 \mu \mathrm{m}$ polyester base. The film of the detector can record alpha particles of energy range $0.1 \mathrm{MeV}$ to $4.8 \mathrm{MeV}$ [13].

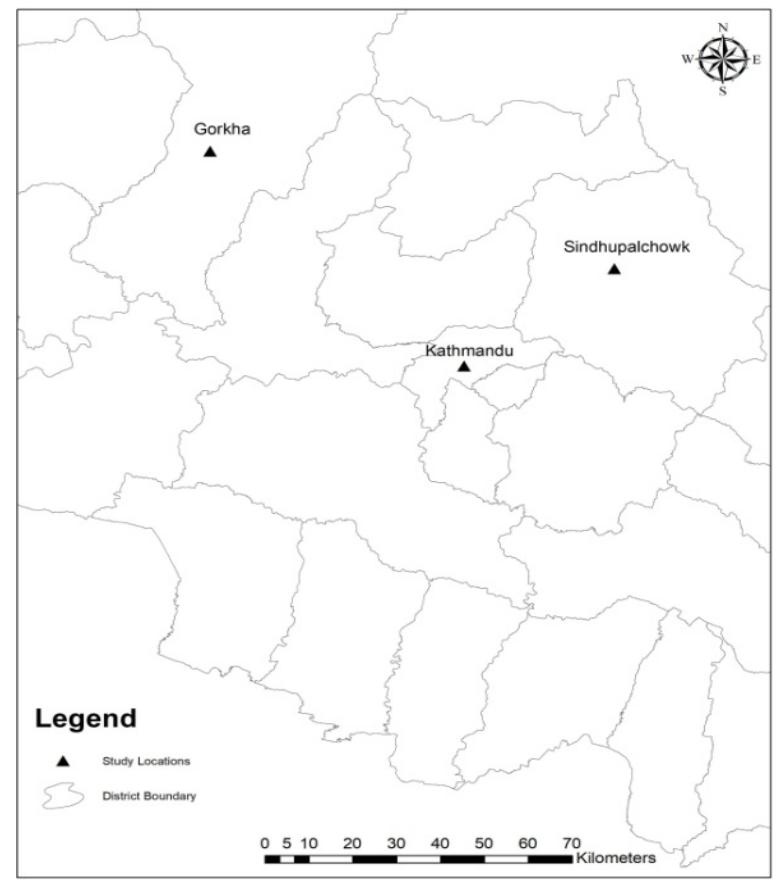

Fig.1: Map of study areas.

A total of 90 dosimeters were fixed in the dwellings of study area out of which 68 detectors were retrieved. The detectors were placed on ground floor approximately $1.5 \mathrm{~m}$ above the ground level and were exposed for about 100 days (May to August, 2017). The detectors were read at Dosirad, France. Exposed films were etched on $10 \%$ analytical grade $\mathrm{NaOH}$ bath for about 75 to 100 minutes at constant bath temperature of $60^{\circ} \mathrm{C}$. After this, films were washed by acidified water $(\mathrm{HCl}$ upto $\mathrm{pH} 3$ ) for 30 minutes and final rinse of around 2 minutes at $20^{\circ} \mathrm{C}$ by distilled water was done. The etched tracks were counted using a binocular optical research microscope at magnification 400X. The radon concentrations were used to calculate Annual Effective Dose (AED) using the UNSCEAR, 2000 model [1]. 
$\mathrm{AED}(\mathrm{mSv} / \mathrm{Yr})=\mathrm{C}_{\mathrm{Rn}} \times \mathrm{E} \times \mathrm{T} \times \mathrm{D}$ where, $\mathrm{C}_{\mathrm{Rn}}$ - Radon Concentration $\left(\mathrm{Bq} / \mathrm{m}^{3}\right)$.

E-Indoor equilibrium factor $(0.4 ;[1,7])$

$\mathrm{T}$-Time in hours per year spent indoor

D-Dose conversion factor (9nSv/Bq.h.m ${ }^{3}$; [1]) 6000 hours per year was considered to be total time spent indoors by the inhabitants following a questionnaire. Excess Lifetime Cancer Risk (ELCR) was calculated as [14].

$$
\mathrm{ELCR}=\mathrm{AED} \times \mathrm{DL} \times \mathrm{RF}
$$

where, DL- Duration of Life (70.2 years; [15])

RF- Fatal Cancer Risk per Sievert $\left(5.5 \times 10^{-2} ;[16]\right)$

Lung's cancer cases per year per million people (LCC) were calculated as [17].

$$
\mathrm{LCC}=\mathrm{AED} \times 18 \times 10^{-6}
$$

\section{Results and Discussions}

\subsection{Radon concentrations}

The indoor radon concentrations were measured in dwellings of different places of Kathmandu valley, Gorkha and Sindhupalchowk districts, which are shown in figure 2, 3 and 4 respectively. As radon concentrations generally follow a log normal distribution [14] the measured radon concentrations also were log-normally distributed (at 0.05 level, Shapiro-Wilk test).

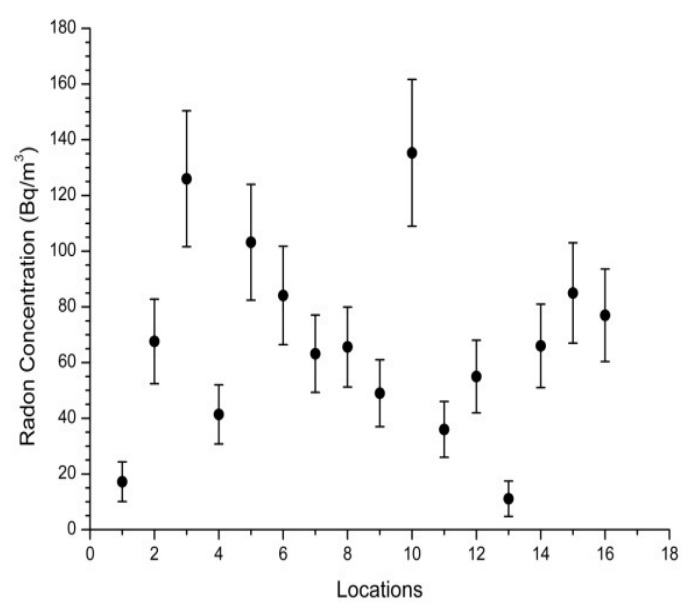

Fig.2: Radon Concentrations in dwellings of Kathmandu Valley.
Radon concentrations varied in different dwellings in Kathmandu valley with the lowest concentration of $11 \pm 6 \mathrm{~Bq} / \mathrm{m}^{3}$ to highest of $135 \pm 26 \mathrm{~Bq} / \mathrm{m}^{3}$. The arithmetic average, geometric average and median value for the concentrations were $67.63 \mathrm{~Bq} / \mathrm{m}^{3}$, $57.26 \mathrm{~Bq} / \mathrm{m}^{3}$ and $66 \mathrm{~Bq} / \mathrm{m}^{3}$ respectively. Out of studied 16 dwellings of Kathmandu valley $81 \%$ of dwellings had radon concentration below $100 \mathrm{~Bq} /$ $\mathrm{m}^{3}$ and remaining $19 \%$ had in between $100-150 \mathrm{~Bq} /$ $\mathrm{m}^{3}$.

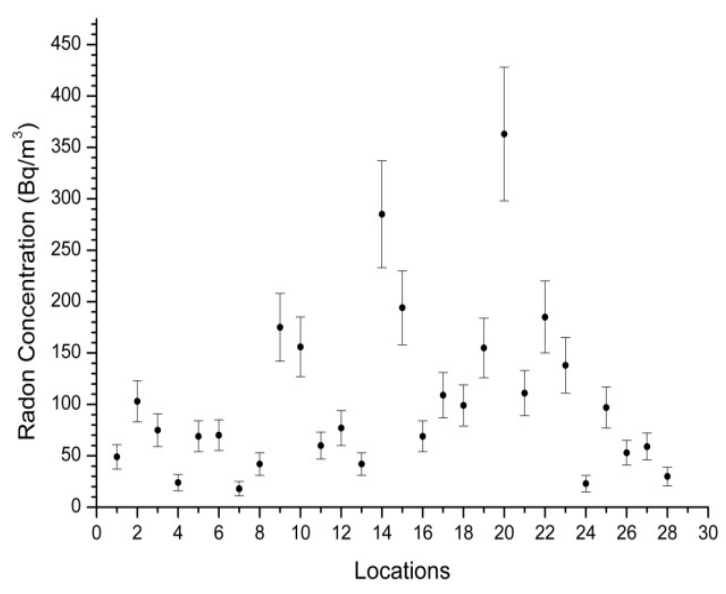

Fig.3: Radon Concentrations in dwellings of Gorkha.

The minimum, maximum and average radon concentrations in Gorkha districts were $18 \pm 7 \mathrm{~Bq} / \mathrm{m}^{3}$, $363 \pm 65 \mathrm{~Bq} / \mathrm{m}^{3}$ and $104.64 \mathrm{~Bq} / \mathrm{m}^{3}$ respectively with geometric mean of $80.63 \mathrm{~Bq} / \mathrm{m}^{3}$ and median value $76 \mathrm{~Bq} / \mathrm{m}^{3}$. In Gorkha, $61 \%$ of the dwellings had concentrations below $100 \mathrm{~Bq} / \mathrm{m}^{3}, 36 \%$ have concentrations in between $100-300 \mathrm{~Bq} / \mathrm{m}^{3}$ and remaining 3\% had concentrations above $300 \mathrm{~Bq} / \mathrm{m}^{3}$. The indoor radon Concentration in Sindhupalchowk ranged from $14 \pm 6 \mathrm{~Bq} / \mathrm{m}^{3}$ to $397 \pm 71 \mathrm{~Bq} / \mathrm{m}^{3}$ with an arithmetic mean of 78.46 $\mathrm{Bq} / \mathrm{m}^{3}$, geometric mean of $60.78 \mathrm{~Bq} / \mathrm{m}^{3}$ and the median value of $65.5 \mathrm{~Bq} / \mathrm{m}^{3}$. In this district, $79 \%$ of dwellings had concentrations below $100 \mathrm{~Bq} / \mathrm{m}^{3}$, $17 \%$ were in between $100-300 \mathrm{~Bq} / \mathrm{m}^{3}$ while only $4 \%$ were above $300 \mathrm{~Bq} / \mathrm{m}^{3}$. 
A comparative representation of radon concentrations in Gorkha, Kathmandu and Sindhupalchowk has been shown in the figure 5. It is observed that radon concentrations in Gorkha and Sindhupalchowk were comparatively higher than those of Kathmandu valley. The variation in radon concentrations might be due to difference in topography of locations, ventilation systems and building materials used in the dwellings $[9,10]$. The permissible limit for radon concentration is $300 \mathrm{~Bq} / \mathrm{m}^{3}[18]$ and in this study only two of the measurements, $397 \pm 71 \mathrm{~Bq} / \mathrm{m}^{3}$ (Sindhupalchowk) and $363 \pm 65 \mathrm{~Bq} / \mathrm{m}^{3}$ (Gorkha), were observed above the limit. Both the dwellings were old aged, made from mud with several cracks, fissures and fractures due to devastating earthquake. Furthermore, poor ventilation system was also observed in both cases.

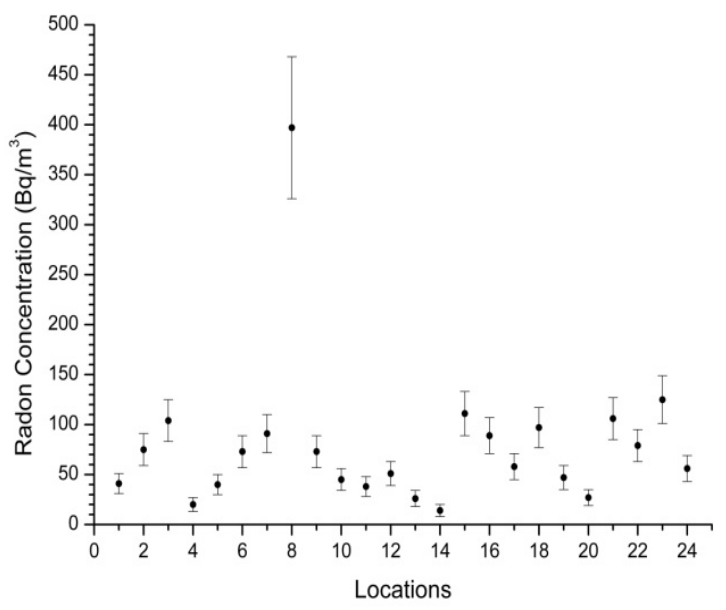

Fig.4: Radon concentrations in dwellings of Sindhupalchowk.

The overall average radon concentration of study locations was $83.57 \mathrm{~Bq} / \mathrm{m}^{3}$ which is lower than those reported in the dwellings of Hemavathi river basin, Karnatak, India $\left(99.35 \mathrm{~Bq} / \mathrm{m}^{3} ;[9]\right)$, Lahore and Islamabad, Pakistan $\left(135.25 \mathrm{~Bq} / \mathrm{m}^{3}\right.$ and 112.5 $\mathrm{Bq} / \mathrm{m}^{3}$ respectively; $[19,20]$ ), Shenyan and Gansu, China (115.7 and 222.9 Bq/ $\mathrm{m}^{3}$ respectively; [21] ), nationwide average of Korea (102 Bq/m $\mathrm{m}^{3}$; [22] ), nationwide average of U.K. (101 Bq/m ; [23] ), Fredicton and Halifax of Canada $\left(138 \mathrm{~Bq} / \mathrm{m}^{3}\right.$ and $259 \mathrm{~Bq} / \mathrm{m}^{3}$ respectively; [24] ). However, the average of this study was higher than those calculated in the dwellings of Kathmandu valley, Nepal $\left(80 \mathrm{~Bq} / \mathrm{m}^{3} ;[25,26]\right)$, nationwide average of Japan $\left(14.3 \mathrm{~Bq} / \mathrm{m}^{3}\right.$; [27]) and indoor radon of Meghalaya, India (59.9 Bq/m³ ; [10]) . In addition this average was slightly more than double the world average indoor radon concentration of 40 $\mathrm{Bq} / \mathrm{m}^{3}[1]$. The higher radon concentrations in some dwellings might be due to following reasons.

- Cracks, fissures and fractures in the basement and wall of the house due to earthquake

- Higher uranium content in the soil

- High permeability and porosity of bedrock

- Some old houses built from mud and wood

- Poor ventilation condition in some houses

- Some houses built on old landslide deposits

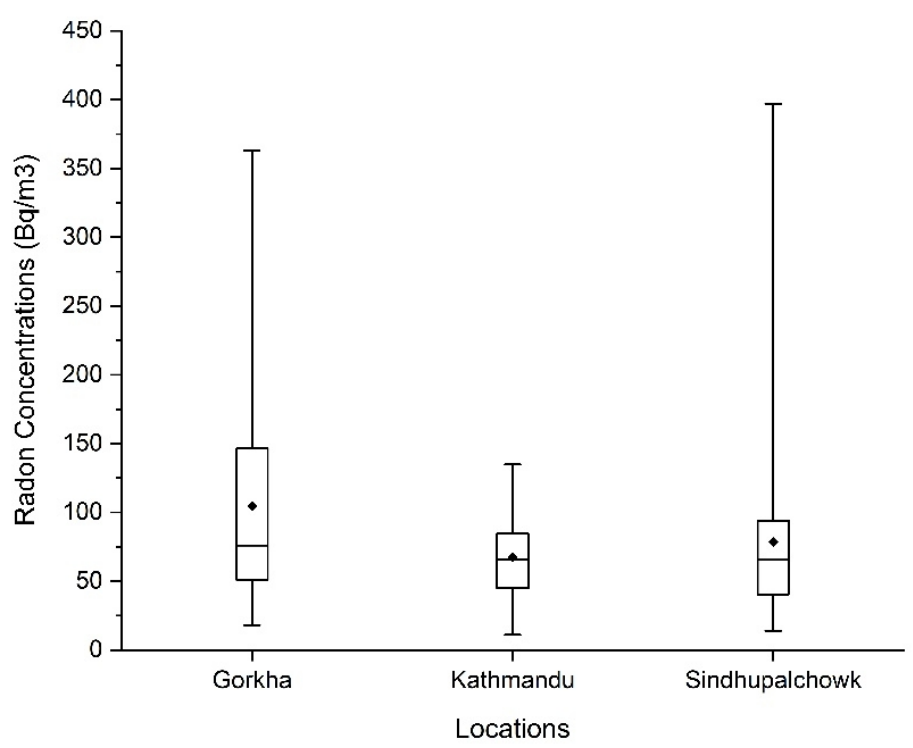

Fig.5: Box plot of radon concentrations. 


\subsection{Annual Effective Dose}

The radon concentrations obtained in the study of Kathmandu valley, Gorkha and Sindhupalchowk districts were used to estimate the annual effective dose (AED) to the inhabitants using UNSCEAR, 2000 model. The AED due to radon received by residents of Kathmandu valley, Gorkha and Sindhupalchowk districts are shown in figure 6,7 and 8 respectively.

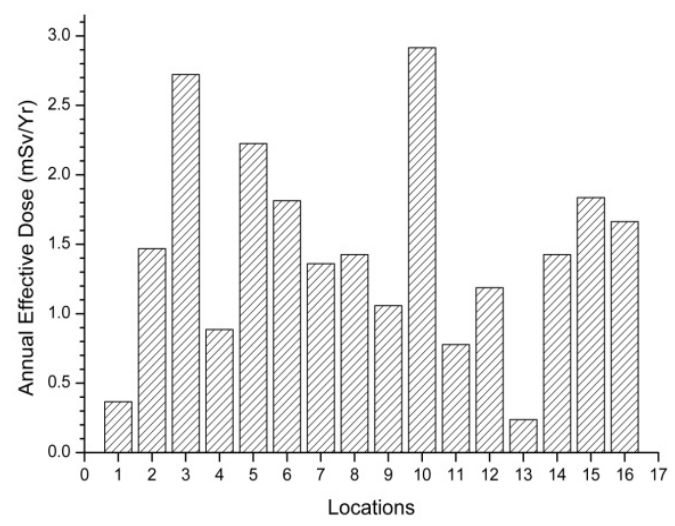

Fig.6: Annual effective dose for Kathmandu valley.

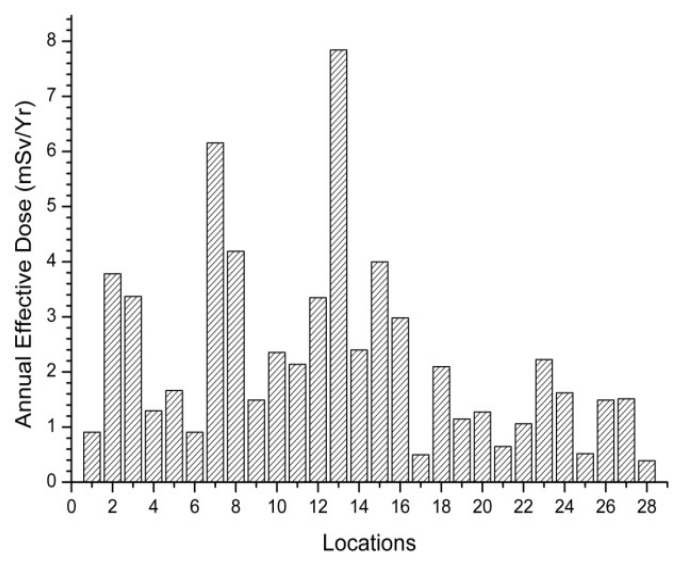

Fig.7: Annual effective dose for Gorkha.

The dose in dwellings of Kathmandu valley varied from $0.24 \mathrm{mSv} / \mathrm{y}$ to $2.92 \mathrm{mSv} / \mathrm{y}$ with an arithmetic average of $1.46 \mathrm{mSv} / \mathrm{y}$. For Gorkha dose were reported to lie between $0.39 \mathrm{mSv} / \mathrm{y}$ and $7.84 \mathrm{mSv} / \mathrm{y}$ with an average of $2.26 \mathrm{mSv} / \mathrm{y}$. Similarly, for Sindhupalchowk, the dose ranged from $0.30 \mathrm{mSv} / \mathrm{y}$ to $8.58 \mathrm{mSv} / \mathrm{y}$ with an average of $1.69 \mathrm{mSv} / \mathrm{y}$. Relatively higher doses were observed in Gorkha which might be attributed to geological variations and nearness to the epicenter of 2015 earthquake. The average doses of all three study locations were higher than the world mean dose from environmental radon of $1.15 \mathrm{mSv} / \mathrm{y}$ [1]. However the average doses were below the action level of 3 to $10 \mathrm{mSv} / \mathrm{y}[7,16]$.

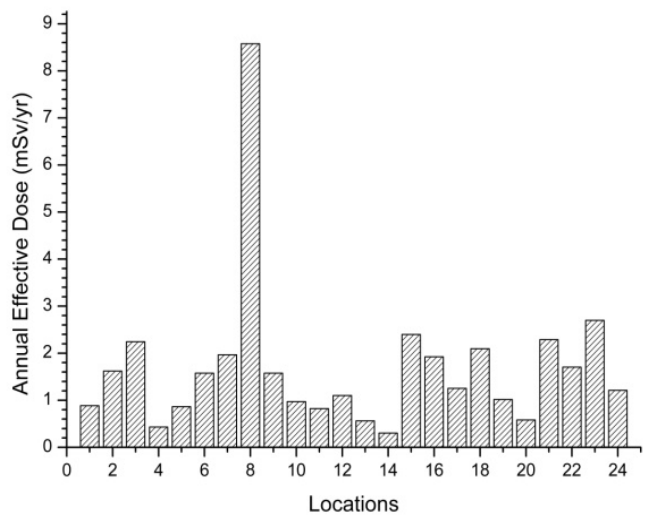

Fig.8: Annual effective dose for Sindhupalchowk.

The average AED was used to determine Excess Lifetime Cancer Risk (ELCR), which was calculated as $0.56 \%, 0.87 \%$ and $0.65 \%$ for Kathmandu valley, Gorkha and Sindhupalchowk respectively. The conversion factor of $18 \times 10^{-6}$ $/ \mathrm{mSv}$ [17] was used to determine indoor radon induced lungs cancer risk. The lungs cancer cases per year per million persons were 26.28, 40.68 and 30.51 for Kathmandu valley, Gorkha and Sindhupalchowk respectively.

\section{Conclusion}

The radon concentrations in Kathmandu valley, Gorkha and Sindhupalchowk districts were measured and AED of the study areas were calculated. Relatively higher dose were observed in Gorkha. The annual doses due to radon were below ICRP recommended action level of $10 \mathrm{mSv} / \mathrm{y}$. Thus, 
there are no significant radiological health hazards to the population and the immediate counter measures are not necessary. However increased ventilation system of houses can be suggested to further reduce the radon concentrations in the dwellings.

All the study areas lie in mid hilly region of Nepal where it is very cold during November to March. As the present study was carried out during summer, it is recommended to have indoor radon measurements in winter season when poor ventilation system is expected which might attribute to higher radon concentrations.

\section{Acknowledgments}

The authors gratefully acknowledge Nepal Academy of Science and Technology (NAST) in funding the research work. We are also thankful to the Dosirad Laboratory, France for track analysis. Owners of the dwellings of study area are also highly appreciated.

\section{References}

[1] United Nations Scientific Committee onthe Effects of Atomic Radiation, Sources and Effects of Ionizing Radiation. UNSCEAR 2000 Report to the General Assembly, with scientific annexes, UNSCEAR, New York, (2000).

[2] International Agency for Research on Cancer, IARC Monographs on the evaluation of the carcinogenic risks to humans: Man-made mineral fibres and Radon, In Volume 43, WHO, Lyon, (1988).

[3] P.M. Lantz et al., Radon, smoking, and lung cancer: The need to refocus radon control policy, American Journal of Public Health 103(3) (2013) 443-447.

https://doi.org/10.2105/AJPH.2012.300926

[4] D.L. Preston et al., Studies of mortality of atomic bomb survivors, Report 13: solid cancer and noncancer disease mortality, Radiation Research 160(4) (2003) 381-407. https://doi.org/10.1667/RR3049

[5] J. H. Lubin et al., Radon-exposed underground miners and inverse dose-rate (Protraction enhancement) effects, Health Physics 69(4) (1995) 494-500.

[6] M. Al-Zoughool,D. Krewski, Health effects of radon: A review of the literature, International Journal of Radiation Biology 85(1) (2009) 57-69. https://doi.org/10.1080/09553000802635054

[7] International Atomic Energy Agency, Radiation Protection and Safety of Radiation Sources: International Basic Safety Standars, General Safety Requrements Part 3 No. GSR Part 3, IAEA, Vienna, (2014).

[8] National Seismological Centre: Earthquakes 2015, Retrieved December 10 http://seismonepal.gov.np/earthquakes/

[9] R.S. Niranjan et al., Concentration of radon in dwellings of Hemavathi river basin, Karnataka, India. Radiation Protection Dosimetry 181(3) (2018) 269-276. https://doi.org/10.1093/rpd/ncy023

[10] A. Pyngrope et al., Study of indoor radon, thoron and their progeny in South West Khasi Hills district of Meghalaya, India. Radiation Protection Dosimetry 189(3) (2020) 347-353. https://doi.org/10.1093/rpd/ncaa048

[11] V. Walia et al., Earthquake Prediction Studies Using Radon as a Precursor in N-W Himalayas, India: A Case Study. Terrestrial, Atmospheric and Oceanic Sciences 16(4) (2016) 775.

[12] P. Parajuli et al., Study of Radon Exhalation Rate in Soil Samples of Kathmandu Valley Using Passive Detector LR115, International Journal of Chemical and Physical Sciences 4 (4) (2015) 3039 .

[13] Dosirad, LR115 films: Descriptions plus Instructions for use, Pierrelatte, (2010).

[14] M. Quarto et al., Radon exposure assessment and relative effective dose estimation to inhabitants of Puglia region, South Italy, International Journal of Environmental Research and Public Health 12 (2015) 14948-14957. https://doi.org/10.3390/ijerph121114948

[15] World Health Rankings: Live longer live better, Retrieved December 19, (2018), from https://www.worldlifeexpectancy.com/nepal-lifeexpectancy.

[16] International Commission on Radiological Protection, The 2007 Recommendations of the International Commission on Radiation Protection, ICRP Publication 103, Annals of the ICRP, 
(2007).

[17] R. Crameri,W. Burkart, The radon problem, International Journal of Radiation Applications and Instrumentation, Part C, Radiation Physics and Chemistry 34(2) (1989) 251-259.

[18] World Health Organization, WHO Handbook on Indoor Radon: A Public Health Perspective ( $\mathrm{H}$. Zeeb \& F. Shannoun, Eds.), (2009).

[19] N. Ali et al., Radon doses in the indoor environments of Murree and Islamabad, Pakistan: A comparison of active and passive techniques, Indoor and Built Environment 25(6) (2016) 883894.

https://doi.org/10.1177/1420326X15588567

[20] R. Najeeb et al., Determination of Radiological doses of Radon and Natural Radionucleides in the Open Environment of the Lahore and Kasur districts, Pakistan, International Journal of Scientific Research 14 (2005) 11-17.

[21] J.H. Lubin et al., Risk of lung cancer and residential radon in China: Pooled results of two studies, International Journal of Cancer 109(1) (2004) 132-137.

https://doi.org/10.1002/ijc.11683
[22] M. Kwon et al., Nationwide survey [2013-2014] of indoor radon at home in Korea, 2014.

[23] D.M. Rees, C.A. Miller,Radon in Homes in England: 2016 Data Report, Oxfordshire, 2016.

[24] J. Chen et al.,An update on thoron exposure in Canada with simultaneous $222 \mathrm{Rn}$ and $220 \mathrm{Rn}$ measurements in fredericton and halifax, Radiation Protection Dosimetry 147(4) (2011) 541-547. https://doi.org/10.1093/rpd/ncq567

[25] D. Thapa, B.R. Shah, Residential radon concentrations in kathmandu valley using solid state nuclear track detectors, Master Proceedings of American Association of Radon Scientists and Technologists, Charleston, South Carolina, USA, (2014).

[26] B.R. Shah et al., Indoor Radon survey in Nepal using passive technique solid state nuclear track detector, International Journal of Clinical and Biomedical Research 1(4) (2015) 7-13.

[27] G. Suzuki et al., A Nation-Wide Survey on Indoor Radon from 2007 to 2010 in Japan, Journal of Radiation Research 51(6) (2010) 683-689. https://doi.org/10.1269/jrr.10083 